Stakeholding as a New Development Strategy for Saudi Arabia

Giacomo Corneo

School of Business \& Economics

Discussion Paper

Economics

$2010 / 20$

978-3-941240-32-2 


\title{
Stakeholding as a New Development Strategy for Saudi Arabia
}

\author{
by \\ Giacomo Corneo*
}

September 2010

\begin{abstract}
The transition from an oil-based to a knowledge-based economy requires that the Saudi population dramatically increases its level of human capital. This paper argues that noncognitive skills may be a bottleneck in the formation of human capital and proposes a policy to indirectly strengthen those skills. The core of the proposal is a government-financed gift to each Saudi citizen reaching adult age, the SSGY.
\end{abstract}

Keywords: Saudi Arabia, Stakeholder Society, Value Systems, Economic Development.

JEL Classification: O0, Z1.

Acknowledgement: This paper builds on and develops a lecture that I delivered at the King Faisal Center for Research and Islamic Studies, Riyadh, in 2009. I thank the audience for helpful comments as well as Giacomo Luciani and Martin Schreiner for discussion and encouragement.

* Free University of Berlin, CEPR London, CESifo Munich, IZA Bonn. Address: Department of Economics, Free University of Berlin, Boltzmannstr. 20, 14195 Berlin, Germany. Email: giacomo.corneo@fu-berlin.de. 
The single most relevant feature of the Saudi economy is its heavy reliance on an exhaustible resource, oil. That feature implies that the long-term prosperity of Saudi society crucially depends on its ability to save and prepare for a time when oil will have become economically irrelevant. Over the next decades, a transition from an oil-based economy to a diversified knowledge-based economy should be accomplished. Along the way, natural wealth has to be transformed into man-made wealth, i.e. physical capital and human capital embodied in the Saudi population. Saudi Arabia still has huge oil reserves and the time horizon for a Saudi nonoil economy is a relatively distant future. Yet, it should start the preparation early since the overall required adjustment is large. Today, the oil sector directly contributes about 40 percent of Saudi GDP and 90 percent of Saudi exports. Oil revenue represents some 80 percent of government revenue. Progressively eliminating dependence on an exhaustible resource that is likely to be depleted in the course of the next two or three generations is the main economic challenge facing Saudi Arabia.

During the last four decades, the Kingdom of Saudi Arabia has made an immense progress, not only in economic terms but also in terms of the education and health standards enjoyed by its citizens. One can appreciate that progress by looking at the growth of per-capita GDP, university enrollment rates, and life expectancy as well as by looking at the decline of infant mortality rates. ${ }^{1}$ One may see those achievements reflected in the majestic towers of Riyadh and in the creation of entirely new economic cities. Yet, even splendor carries a risk, as too much of it can make you blind. This paper argues that there is a fundamental factor of economic development that has so far been neglected in the development strategy followed by the Saudi government. That factor refers to those non-cognitive skills of people that motivate and guide agents’ decision-making in advanced market economies.

"The most valuable of all capital is that invested in human beings; and of that capital the most precious part is the result of the care and influence of the mother". 120 years after Alfred Marshall wrote that sentence, human capital has become the centerpiece of knowledge-based economies. In high-income countries, human capital accounts for about 80 percent of total wealth and is the main engine of economic growth. Such a large amount of human capital takes

\footnotetext{
1 Recent accounts of the progress made by the economy of Saudi Arabia as well as of some of its problems are offered e.g. by Brach (2009) and Rivlin (2009). On the political economy of rent extraction and distribution, see e.g. Beblaw and Luciani (1987); related formal models are offered by Shahnawaz and Nugent (2004), van der Ploeg (2010) and Wirl (2009).
} 
a lot of time to be accumulated. Human capital does not simply spring out of newly built schools and universities. It is the result of a society-wide long-term process in which not only the formal education system but also families and workplaces play a major role. Along with cognitive ability, intrinsic motivation for learning and working, initiative, thrift, and perseverance determine how fast human capital accumulates in society. In high-income countries, attitudes and values that facilitate human capital formation are largely cultivated and transmitted by families. As I argue below, there is a serious risk for Saudi Arabia that generous public investment in formal education may fail to deliver the expected amount of human capital because the needed complementary attitudes and values are too weak.

The aim of this paper is to propose a reform project that circumvents that risk. The next Section presents results from scholastic achievement tests that help to justify the concern about a lasting deficit of human capital in the Saudi population. The core of the paper is Section 3 where the reform project is formulated and motivated. At the center of the project there is a social grant that all Saudis entering adulthood should receive from the government. The issue of how to finance that grant is attacked in Section 4 . Section 5 briefly concludes.

\section{Scholastic achievement as an indicator of future human capital}

Society invests in the human capital of the next generation at schools, in firms and in families. The returns from such investments materialize through increased labor productivity and take the form of increased wages, salaries and entrepreneurial incomes for the next generation. What are the expected returns of current Saudi investment in human capital?

Predicting the yields of current human capital formation in absolute terms would require making several heroic assumptions. A less demanding exercise is to assess the returns of Saudi investments relative to those of other countries. It may be performed by simply comparing international standardized tests of scholastic achievement. As shown by empirical studies, scholastic achievement tests are a powerful predictor of wages and lifetime income. ${ }^{2}$ By comparing the achievement of Saudi pupils with the achievement of pupils in other countries one may try to guess the relative productivity of those individuals when they will have reached working age and be participating in the labor market. ${ }^{3}$

\footnotetext{
2 See e.g. Heckman et al. (2006).

3 There is also evidence that scholastic achievement of individuals translate into macroeconomic growth. For instance, Mitch (1999) corroborates the view that education played a prominent role in the emergence of new in-
} 
Saudi Arabia participated in the fourth assessment of the Trends in International Mathematics and Science Study (TIMMS) conducted by the International Association for the Evaluation of Educational Achievement. In 2007, standardized tests were administered to a sample of $8^{\text {th }}$-grade students in the Kingdom and a host of other countries to assess proficiency in mathematics and science. In mathematics, Saudi Arabia reached rank 48 among 48 countries. The performance gap was substantial in comparison with many countries; for instance, while only 18 percent of Saudi students managed to achieve at least the lowest benchmark for the mathematics test, in Egypt 47 percent of the tested pupils reached that benchmark and in Malaysia 82 percent did. In particular, the Kingdom ranked lower than a number of countries that spend significantly less on education per-pupil than Saudi Arabia, like Jordan, Syria, and Tunisia. The science test was slightly better for the Kingdom, as Saudi Arabia ranked 43 out of 48. Still, the gap as compared to countries like Jordan, Malaysia and Egypt was substantial.

Results about the attainment of the intermediate benchmarks in mathematics and science mirrored those about the lowest benchmarks. The following table reports how the Kingdom compared to other Arab countries:

dustries in Great Britain at the time of its industrial revolution; Becker et al. (2010) show that education was key to allow Prussia for catching up with Britain to the new technological frontier during the $19^{\text {th }}$ century. 
Performance of $8^{\text {th }}$-Grade Students at TIMMS 2007 in ten selected countries.

\begin{tabular}{|c|c|c|}
\hline Rank & $\begin{array}{l}\text { Percentage of Students Reaching the } \\
\text { Mathematics Intermediate Bench- } \\
\text { mark }\end{array}$ & $\begin{array}{l}\text { Percentage of Students Reaching the } \\
\text { Science Intermediate Benchmark }\end{array}$ \\
\hline 1 & Malaysia (50) & Jordan (56) \\
\hline 2 & Jordan (35) & Malaysia (50) \\
\hline 3 & Egypt (21) & Bahrain (49) \\
\hline 4 & Tunisia (21) & Syria (39) \\
\hline 5 & Bahrain (19) & Oman (32) \\
\hline 6 & Syria (17) & Tunisia (31) \\
\hline 7 & Oman (14) & Kuwait (28) \\
\hline 8 & Kuwait (6) & Egypt (27) \\
\hline 9 & Qatar (4) & Saudi Arabia (18) \\
\hline 10 & Saudi Arabia (3) & Qatar (11) \\
\hline
\end{tabular}

As mentioned above, empirical studies that track the same individuals from childhood to adulthood find a close correlation between scholastic achievement and earnings. So, suppose that the whole oil had disappeared from Saudi Arabia and that human capital were the only source of income. Assume that average human capital in a country is proportional to the educational achievement of the $8^{\text {th }}$-grade students of that international test. In that purely hypothetical non-oil situation, Saudis' income would be much lower than Egyptian average income. To appreciate what this means, recall that Egyptian per-capita GDP is currently worth only one fourth of per-capita GDP in Saudi Arabia. 
While it is possible that a relatively low level of skills during secondary school be compensated by fast skill upgrading during tertiary education, this is not what studies of human development suggest. ${ }^{4}$ University enrollment is high in Saudi Arabia in comparison to most Arab countries. However, it displays a strong bias against science and technology, both of which are crucial for increasing future labor productivity. Thus, in 2004 only 9 percent of Saudi graduates qualified in science or technology, as compared to 19 percent in Bahrain, 29 percent in Iraq, 25 percent in Jordan, 22 percent in Lebanon, and 19 percent in Morocco. ${ }^{5}$

High levels of scholastic achievement tests signal high future productivity of the next generation because they are the result of skills that individuals later use in working activities. Psychologists and economists distinguish between two types of skills: cognitive and noncognitive skills. Cognitive skills are close to what is called "intelligence” in common parlance: problem-solving ability, knowledge and wisdom. Non-cognitive skills refer to “character” and include motivation, initiative, perseverance, conscientiousness, and a forward-looking attitude. Cognitive and non-cognitive skills develop at different pace at various stages of childhood and youth and interact with each other. Both are fundamental determinants of outcomes in terms of scholastic achievement and professional success. Intelligence without character produces bohemians at best, public dangers at worst; character without intelligence cannot produce the creative individuals needed for economic and social progress. Cognitive as well as non-cognitive skills are therefore necessary for human development and economics growth.

For Saudi Arabia, this means that a successful transition from the oil-based economy to the knowledge-based economy requires an enhanced effort to form both cognitive and noncognitive skills. Investing in formal education is a necessary but not a sufficient condition for a speedy improvement of individual capabilities. In countries with a high level of human capital, the education system is one leg of the transmission of cognitive and, to a lesser extent, noncognitive skills. The other leg is the family. Within families, parents often try to transmit some of their professional knowledge and wisdom to their children. More importantly, parents play a fundamental role in shaping the character of their children, whether the parents realize it or not. Their example can namely transmit a sense of purpose, a thirst of knowledge, a work ethic, discipline, and a sense of responsibility. Such non-cognitive skills are crucial for translating the abstract notions presented by teachers at school into concrete knowledge of the individual, ready to be activated when the individual is performing an economic activity.

\footnotetext{
4 See e.g. Cunha and Heckman (2009).

5 Those numbers are reported by Rivlin (2009, p. 224).
} 
Families do not always instill values and attitudes that promote human capital formation. ${ }^{6}$ Parents are poor providers of non-cognitive skills that are conducive to pro-learning and pro-work attitudes if they do not possess them in the first place and exhibit them in their everyday life. This is a common finding in studies of disadvantaged adolescents in OECD countries, one that has important implications for their social policy. One may conjecture that a similar link between the work experience of parents and their children's skill formation exists in the case of the ordinary population of countries that derive the bulk of their income from natural resources rather than from the activation of their human capital.

Consider the current role of work for Saudi adults. According to recent statistics, the Saudi population aged 20-64 amounted to 8,523,000 individuals in 2007. This is the order of magnitude of the potential Saudi workforce. Official statistics report that some 3,585,000 Saudis were employed which suggests that more than half of the potential Saudi labor force was not utilized. Because of various statistical problems, such an assessment is likely to grossly overstate the actual contribution of Saudi labor to domestic production. According to a recent study, the Saudi employment rate in 2007 was merely 24.5 percent and it was concentrated in the public sector. ${ }^{7}$ By comparison, employment rates in OECD countries are close to 70 percent and only one employed person out of ten works for the government. The comparison is even more extreme if one looks at female employment. While in OECD countries employment rates for women are only a few percentage points below the employment rates for men, in the case of the Saudi population the female employment rate is only a sixth of the male employment rate.

From a long-run perspective, say the one of current Saudi grandchildren, this state of affairs does not justify economic optimism. In order to achieve the transition from an oil-based to a knowledge-based economy it is not enough to endow your grandchildren with new universities, increase their enrollment rate, and facilitate their integration in the labor market by means of a Saudization policy. You also have to instill a sense of responsibility and purpose, a work ethos and a learning ethos in the young generations. This process may not spontaneously arise because the share of the population in working age that is engaged in production activities that make use of advanced knowledge and generate a large amount of value added is low, especially in the case of women.

\footnotetext{
6 Corneo and Jeanne (2010) offer an endogenous growth model where parents transmit values to their children and "wrong” values can cause a poverty trap.
} 
In order to break the dependence on oil and become a knowledge-based economy, Saudi Arabia should accompany investments in formal education by a strengthening of those attitudes and values that are conducive to human capital formation. Recent research on how value systems evolve strongly suggests that changes in the economic opportunities faced by people are a powerful engine of value change. ${ }^{8}$ That is, far from being immutable ethnic traits, values and attitudes do respond to material incentives - although the reaction time may span one generation or more. Based on that insight, I consider an economic policy that opens an entirely new framework of life opportunities and by doing this promotes the kind of values and attitudes needed to build the new knowledge-based economy.

In what follows I propose that a program of wealth transfer to the Saudi youth be launched under the auspices of the King of Saudi Arabia and run by its government. I refer to that program as to the Saudi Start-up Gift to the Youth (SSGY). Under that program, every Saudi citizen reaching adulthood would inherit an equal amount of wealth from society. A gift of 100,000 Saudi riyals is proposed as a reference for further discussion. ${ }^{9}$

Eligible persons for the start-up gift would be all Saudi citizens, both males and females, with main residence in the country and who have not committed serious crimes. In a given year, all citizens who become adult - say eighteen or twenty-one years old - would receive at their birthday - upon request and verification of eligibility - a large money transfer from a dedicated SSGY-fund. Each individual would be responsible for the use of his or her gift and free to make the best use out of it as seen by the individual, without any restrictions for women. The amount of the gift would be the same for everybody, independently of an individual's personal characteristics and family background, including income and wealth. The level of the gift may be adjusted over time only by the King, in order to take the effects of inflation, economic growth, and positive as well as negative shocks into account.

\footnotetext{
${ }^{7}$ Hertog (2009).

8 Early models of purposively chosen values were offered by Akerlof (1983); recent work on endogenous values includes Akerlof and Kranton (2000), Bisin and Verdier (2000) and Corneo and Jeanne (2009). An overview on value change in many countries is offered by Inglehart and Baker (2000).

9 About ten years ago, Ackermann and Alstott (1999) made a similar proposal for the United States. They proposed that at age 21 each citizen should receive a stake of 80,000 USD from the government. While their proposal was not adopted in the US, a similar but smaller-scale program was launched in the United Kingdom in 2005, the UK Child Trust Fund.
} 
As explained shortly, the SSGY-program should be accompanied by some other policies so as to bring about progress on a number of fronts, the main one being the accumulation of human capital so as to facilitate the transition to a knowledge-based economy. I will detail those accompanying policies while discussing the main beneficial effects that one may expect from such an overall reform. The expected benefits include the following ones:

1. The program will strengthen the sense of responsibility of the youth and encourage the young members of society to think deeper about their life goals and to actively pursue those goals. The anticipation of the gift would prompt the families of prospective receivers and the schools to prepare the receivers for decision-making. In families and schools people will ponder on the appropriate goals in their life and how the gift could best be used to attain those goals. As experience accumulates, prospective receivers and their reference adult persons will increasingly discuss about ways in which people they know used their gift and learn from others' experience; some may have used the gift to cover the set-up costs of a small business, while others may have paid for a university specialization, or invested the money in a mutual fund. Some individuals may have squandered their money. In this novel environment for Saudi society, young people will feel more empowered and responsible for their own fate. Thus, they will focus more attention on self-realization and life planning. However, it will not be a purely individual undertaking but a societal one, since everybody receives the same gift. Being incorporated in a collective discourse, an individual's search for goals and instruments will take the broader concerns of the community into account.

2. The SSGY will eliminate artificial barriers to entrepreneurship and professional specialization set by both mental habits and borrowing constraints. Regarding mental habits, the SSGY will transport the possibilities of becoming an entrepreneur and pursuing a technical or scientific career into the mental horizon of the whole Saudi youth. Usually, mental habits associated with distinctive family backgrounds severely limit the choice set that is effectively perceived by young individuals thinking about their future occupation: doing something very different from what their parents or close relatives do may simply be "unthinkable". This is a reason why the mere supply of education and training by the government is ineffective when parents do not transmit to 
their children an intrinsic motivation for entrepreneurship and learning. As a result, plenty of talents may remain unexploited. For instance, children of public employees that have entrepreneurial talent may never dare to become entrepreneurs; beduins' children that are highly proficient in natural sciences at school may not seriously take the possibility of a scientific career into account. The changes in perspective and novel thoughts brought about by the SSGYprogram will make a breach into those mental habits and enlarge the effective horizon of occupational choice. Regarding borrowing constraints, the SSGY will remove those obstacles to the creation of small enterprises and to investment in human capital that derive from an individual's or his family's insufficient non-human wealth. By eliminating artificial barriers to occupational choice, the SSGY program will improve the allocation of talents to business, technical, and scientific activities and thus contribute to the endogenous development of those human resources that constitute the key factor for the longterm prosperity of the Kingdom.

3. The existence of the SSGY-program will justify significant cuts to distortive public expenditures and a roll-back of stifling bureaucracy. Since all Saudis will have the opportunity to start a business or to acquire a specialization or professional qualification, there will be less pressure on the government to employ people just to provide them with a job. By the same token, subsidies and public lending to promote the establishment of small businesses could be substantially reduced if a SSGY-program were in place. Substantial fiscal savings could also be achieved by cutting subsidies to social housing and rolling back allocations to the Real Estate Development Fund. In this way, bureaucracy may be drastically reduced along with the waste that it causes by prompting rentseeking behavior by citizens. Eliminating ill-targeted subsidies would also eliminate the distortions in individual choices caused by the preferential treatment of some forms of consumption or investment over others.

4. The existence of the SSGY will allow for an extended role of the market in higher education. This is likely to be a crucial step in order to build the new knowledge-based economy. Making higher education respond to supply and demand forces will bring about a reasonably efficient allocation of human and material resources instead of the current serious mismatch between the needs 
of the domestic economy and the qualifications of university graduates. University autonomy and competition should increase, with universities charging tuition fees for what they offer and students effectively demanding quality for what they pay. The SSGY makes student grants and loans - along with their administrative costs - redundant and eliminates the main reason to forbid universities to charge tuition fees. As a consequence, subsidies for institutions of higher education could be substantially reduced. Access to student dormitories may also be allocated through the market, thus eliminating another source of deadweight losses. A market for higher education with autonomous universities competing with each other will develop, with no harm for the relatively poor regions of the Kingdom. In relative terms, the poor regions will actually be those profiting most from the program, so that the latter will also contribute to reduce significant interregional disparity in Saudi Arabia.

5. The program will provide a remarkable support to young couples that wish to create a family by giving them an independent financial basis. The gift from the government could be used to buy a flat or a house, something which is strongly needed but that some 45 to 60 percent of Saudis currently cannot afford. In this way, a basic security level would be obtained by citizens at a crucial stage of their lifecycle. In turn, the SSGY would substantially diminish the burden carried by middle-class and relatively poor people with many children in marriage age.

6. The SSGY-program will offer young women a material and spiritual basis for achieving economic independency. Putting the creativity of women to the service of the Kingdom is not only an obvious way to raise current non-oil GDP. In view of the special role of mothers already stressed by Alfred Marshall, it is also a crucial ingredient for increasing the future level of human capital. Female participation in the economy will endow mothers with those skills that once transmitted to their children will facilitate their children's accumulation of human capital. In the context of the Saudi labor market, it may be crucial to produce a critical mass effect. This means that many more women may prepare to actively participate in the economy if they expected many others to do the same. This may occur because gradually mixing the gender composition of workplaces is not a feasible option and/or because social acceptance of 
women's work would be greater if many more women worked. This means that there are multiple equilibria and that an equilibrium different from the current one is possible, one where both society's demand for female work and women's willingness to enter the labor market are much larger than they currently are. The SSGY-program would contribute to coordinate expectations on the good equilibrium and allow female participation to cross the critical threshold, so that a rapid endogenous growth may set in.

7. The gift for the youth will boost both demand and supply of bank and insurance products tailored to the needs of young savers. Some portion of the total gift amount will be saved either to finance consumption at later age or to take advantage of future investment opportunities. Those entitled to the gift will have an incentive to improve their degree of financial literacy, something which would be supported by schools. There will be growth opportunities for the banking and insurance sector, in some areas of which Saudi firms have a comparative advantage, notably in Islamic banking.

8. The SSGY-program will improve social justice by distributing opportunities for self-realization more equally in the Kingdom. Whereas obtaining a job in the public sector is partly a matter of luck and personal connections, the SSGY is a transparent and equal support for everyone. The under-privileged young Saudis will be those benefitting most from the SSGY-program in terms of expected utility. It will be a substantial help not only for those who are materially poor. Through its effect on attitudes, it will also help those who are spiritually poor, i.e. those who are passive, who lack a sense of purpose and a moral anchor and those who are easy prey of false prophets. Since the program is targeted at Saudis and many expatriates live in the Kingdom, it is important that measures be taken to ensure their fair treatment. Two fields where reforms are in order concern the procedures to acquire Saudi nationality and the restrictions on the internal mobility and self-employment of expatriates.

9. The SSGY-program will promote solidarity and acts of loyal citizenship. Humankind is endowed with an inner tendency to reciprocate. Those young people who will receive an explicit gift from the Kingdom that endows them with considerably greater life-shaping opportunities will be in a moral disposition to 
reciprocate. This will generate a long-lasting increase in social cohesion and political stability in Saudi Arabia. Furthermore, as people receive the SSGY, it will become politically easier to raise taxes which in turn make people feel the costs of government spending and thereby increase fiscal discipline.

10. The SSGY-program will increase the international prestige of the Kingdom of Saudi Arabia as a worldwide pioneer in launching a policy that contributes to human development, social justice, and economic efficiency. While the SSGYprogram is a policy that is tailored to the Saudi economy, it may prove an inspiring model for other emerging countries with substantial public financial wealth looking for an alternative to traditional sovereign wealth funds.

\section{$4 \quad$ Financial feasibility}

The financial feasibility of the SSGY-program relies upon the financial reserves accumulated by the Saudi government. Technical implementation would have a part of the government's deposits with the banking sector allocated to a dedicated SSGY-fund. Similarly to a sovereign wealth fund, the SSGY-fund would invest its endowment in the capital market; the ensuing returns would be used to finance the SSGY-program.

In order to give an idea of the order of magnitude of the SSGY-program in relation to Saudi public finances, suppose that every year 500,000 young Saudis receive from the government 100,000 SR. The total expenditure would then amount to 50 billion SR, roughly corresponding to a 10 percent increase of public expenditure. However, the net costs to the fisc would be significantly lower because of the concomitant cuts in subsidies and public employment mentioned at points 3 and 4 in the previous Section. There will also be positive indirect effects for the budget due to a stronger economy and therefore larger tax revenues, including the Zakat duty.

Another way to look at the financial burden caused by the SSGY-program is to focus on the associated SSGY-fund. Suppose that the fund should yearly distribute 50 billion SR in real terms in perpetuity. Assuming an average real yearly rate of return on investment of 5 percent, a permanent revenue in that order of magnitude could be generated by a fund worth one trillion SR. According to recent statistics, this is considerably less than the current government deposits with the banking system. Of course, the fiscal savings mentioned above would help to endow the fund. 
When introducing the SSGY, transitional measures would be warranted. First, lack of experience at the beginning of the program may severely undermine people's ability to make good use of the gift. Hence, the government should support decision-makers by information campaigns and advice at the local level. This could be achieved in cooperation with the schools and a number of organizations like the chambers of commerce and industry, institutions providing vocational training, and universities.

Second, a transitional gift scheme is required for fairness reasons. It would be utterly unfair if, say the cohort of those born in 1991 would receive 100,000 SR and those born in 1990 would receive zero. Various ways to solve this problem exist. One may think of a gradual increase of the gift, starting from a low level. Alternatively, one may think of beginning with gifts given also to cohorts older than, say, twenty, with an amount decreasing with age and a gradual concentration of gifts upon the twenty-years-old individuals.

\section{Conclusion}

The transition from an oil-based economy to a dynamic knowledge-base economy is that kind of challenge where there are no forerunners providing one with an illuminating example to follow. Countries facing that challenge have to wisely choose within a large set of policies. Some policies, like substantial public investment in education and health, support to research and development and industrial diversification, are likely to be appropriate for all transition countries and relatively easy to choose. Other policies may be appropriate only for a subset of countries and require governments to take not yet travelled roads. The Saudi Start-up Gift to the Youth may be one of them. 


\section{References}

Ackerman, Bruce and Anne Alstott (1999): The Stakeholder Society, Yale University Press, New Haven.

Akerlof, George (1983): Loyalty filters, American Economic Review 73, 54-63.

Akerlof, George and Raquel Kranton (2000): Economics and identity, Quarterly Journal of Economics 115, 715-753.

Beblaw, Hazem and Giacomo Luciani (eds.) (1987): The Rentier State, Croom Helm, Beckenham.

Becker, Sascha, Hornung Erik and Ludger Woessmann (2009): Catch me if you can: Education and catch-up in the industrial revolution, IZA DP $\mathrm{N}^{\circ} 4556$.

Bisin, Alberto and Thierry Verdier (2000): Beyond the melting pot: Cultural transmission, marriage, and the evolution of ethnic and religious traits, Quarterly Journal of Economics 115, 955-988.

Brach, Juliane (2009): Technology, political economy, and economic development in the Middle East and North Africa, Review of Middle East Economics and Finance, Vol. 5: $N^{\circ} 3$, Article 1.

Corneo, Giacomo and Olivier Jeanne (2009): A theory of tolerance, Journal of Public Economics 93, 691-702.

Corneo, Giacomo and Olivier Jeanne (2010): Symbolic values, occupational choice, and economic development, European Economic Review 54, 237-251.

Cunha, Flavio and James Heckman (2009): The economics and psychology of inequality and human development, Journal of the European Economic Association 7, 320, 364.

Heckman, James, Stixrud, Jora and Sergio Urzua (2006): The effect of cognitive and noncognitive abilities on labor market outcomes and social behaviour, Journal of Labor Economics 24, 411-482.

Hertog, Steffen (2009): Saudization and labour market nationalization policies in other GCC countries: A benchmark exercise, mimeo, Sciences Po, Paris.

Inglehart, Ronald and Wayne Baker (2000): Modernization, cultural change, and the persistence of traditional values, American Sociological Review 65, 19-51. 
Mitch, David (1999): The role of education and skill in the British industrial revolution. In Mokyr, Joel (ed.), The British Industrial Revolution: An Economic Perspective, $2^{\text {nd }}$ edition, pp. 1-127, Westview, Bouolder.

Rivlin, Paul (2009): Arab Economies in the Twenty-First Century, Cambridge University Press, Cambridge.

Shahnawaz, Sheikh and Jeffery Nugent (2004): Is natural resource wealth compatible with good governance? Review of Middle East Economics and Finance, Vol. 2: N 3, Article 1.

Van der Ploeg, Frederick (2010): Voracious transformation of a common natural resource into productive capital, International Economic Review 51, 365-381.

Wirl, Franz (2009): Intertemporal monopolistic pricing of non-durables, Journal of Economics 97, 97-119. 


\section{Diskussionsbeiträge des Fachbereichs Wirtschaftswissenschaft der Freien Universität Berlin}

2010

2010/1 BÖNKE, Timm / Sebastian EICHFELDER

Horizontal equity in the German tax-benefit system

Economics

2010/2 BECKER, Sascha / Dieter NAUTZ

Inflation, Price Dispersion and Market Integration through the Lens of a Monetary

Search Model

Economics

2010/3 CORNEO, Giacomo / Matthias KEESE / Carsten SCHRÖDER

The Effect of Saving Subsidies on Household Saving

Economics

2010/4 BÖNKE, Timm / Carsten SCHRÖDER / Clive WERDT

Compiling a Harmonized Database from Germany's 1978 to 2003

Sample Surveys of Income and Expenditure

Economics

2010/5 CORNEO, Giacomo

Nationalism, Cognitive Ability, and Interpersonal Relations

Economics

2010/6 TERVALA, Juha / Philipp ENGLER

Beggar-Thyself or Beggar-Thy-Neighbour? The Welfare Effects of Monetary Policy Economics

2010/7 ABBASSI, Puriya / Dieter NAUTZ

Monetary Transmission Right from the Start: The (Dis)Connection Between the Money Market and the ECB's Main Refinancing Rates

Economics

2010/8 GEYER, Johannes / Viktor STEINER

Public pensions, changing employment patterns, and the impact of pension reforms across birth cohorts

Economics

2010/9 STEINER, Viktor

Konsolidierung der Staatsfinanzen

Economics

2010/10 SELL, Sandra / Kerstin LOPATTA / Jochen HUNDSDOERFER

Der Einfluss der Besteuerung auf die Rechtsformwahl

FACTS

2010/11 MÜLLER, Kai-Uwe / Viktor STEINER

Labor Market and Income Effects of a Legal Minimum Wage in Germany

Economics

2010/12 HUNDSDOERFER, Jochen / Christian SIELAFF / Kay BLAUFUS / Dirk

KIESEWETTER / Joachim WEIMANN

The Name Game for Contributions - Influence of Labeling and Earmarking on the

Perceived Tax Burden

FACTS 
2010/13 MUCHLINSKI, Elke

Wie zweckmäßig ist das Vorbild der Physik für ökonomische Begriffe und Metaphern Economics

2010/14 MUCHLINSKI, Elke

Metaphern, Begriffe und Bedeutungen - das Beispiel internationale monetäre

Institutionen

Economics

2010/15 DITTRICH, Marcus und Andreas Knabe

Wage and Employment Effects of Non-binding Minimum Wages

Economics

2010/16 MEIER, Matthias und Ingo Weller

Wissensmanagement und unternehmensinterner Wissenstransfer

Management

2010/17 NAUTZ, Dieter und Ulrike Rondorf

The (In)stability of Money Demand in the Euro Area: Lessons from a Cross-Country

Analysis

Economics

2010/18 BARTELS, Charlotte / Timm Bönke

German male income volatility 1984 to 2008: Trends in permanent and transitory income components and the role of the welfare state

Economics

2010/19 STEINER, Viktor / Florian Wakolbinger

Wage subsidies, work incentives, and the reform of the Austrian welfare system Economics

2010/20 CORNEO, Giacomo

Stakeholding as a New Development Strategy for Saudi Arabia

Economics 